\title{
ANALISIS MIGRASI PENDUDUK MELALUI PROGRAM RUMAH SUBSIDI DI DAERAH PINGGIRAN KOTA MEDAN
}

\author{
Zuraidah Adlina* \\ Universitas Islam Sumatera Utara, Indonesia
}

\begin{tabular}{|c|c|}
\hline Article History & Abstrak \\
\hline Received : October 15, 2019 & \multirow{5}{*}{$\begin{array}{l}\text { Tujuan penelitian ini adalah memberikan gambaran migrasi penduduk } \\
\text { kota Medan ke pinggiran kota dengan mengambil Perumahan Subsidi } \\
\text { Griyaland Pecawir, Kabupaten Deli Serdang. Populasi penelitian ini } \\
\text { adalah Masyarakat yang mengambil Perumahan Subsidi Griyaland } \\
\text { Pecawir sebanyak } 300 \text { keluarga yang memiliki hak kepemilikan rumah } \\
\text { subsidi tersebut. Sampel yang digunakan adalah seluruh keluarga yang } \\
\text { memiliki hak kepemilikan rumah subsidi tersebut. Data dikumpulkan } \\
\text { menggunakan angket dan wawancara terkait alasan migrasi penduduk } \\
\text { ke pinggiran kota Medan. Hasil Penelitian menunjukkan bahwa } \\
\text { pembangunan rumah subsidi di daerah pinggiran kota tidak sepenuhnya } \\
\text { mampu mengurangi jumlah pendudukan di daerah perkotaan. Migrasi } \\
\text { penduduk yang seharusnya dapat mengurangi kepadatan penduduk di } \\
\text { daerah perkotaan tidak dapat terlaksana dengan baik. }\end{array}$} \\
\hline Accepted : October 18, 2019 & \\
\hline Published : October 18, 2019 & \\
\hline Kata Kunci & \\
\hline & \\
\hline
\end{tabular}

\section{PENDAHULUAN}

Indonesia pada saat sekarang ini, mulai fokus pada upaya pembangunan infrastruktur yang dapat dinikmati oleh segenap penduduk Indonesia, mulai dari Sabang sampai Merauke. Pembangunan yang dimaksud bukan semata percepatan pertumbuhan ekonomi serta pengentasan kemiskinan, tetapi juga pemerataan penduduk yang menjadikannya lebih demokratis dan partisipatoris (Mulyani, 2016). Pada tahap sekarang ini, pembangunan infrastruktur seperti penyediaan akses jalan, transportasi serta pembangunan ekonomi masyarakat desa menjadi prioritas utama yang digalakkan Pemerintah.

Salah satu tujuan dalam agenda pembangunan dunia adalah menciptakan perkotaan yang inklusif, aman, berketahanan dan berkelanjutan, yang menekankan pada pengelolaan urbanisasi sebagai kesempatan untuk pembangunan di masa mendatang, yaitu menciptakan kota layak yang aman dan nyaman berbasis karakter fisik, keunggulan ekonomi, dan budaya lokal (Wulandari, 2018). Pembangunan di Kota Medan umumnya mencirikan budaya lokal, di mana ornamen gedung maupun pernakpernik yang digunakan mencerminkan kebudayaan Melayu.

Pembangunan Kota Medan bukan hanya menciptakan pertumbuhan ekonomi saja, tetapi juga pertumbuhan penduduk. Laju perkembangan fisik di wilayah perkotaan sangat dipengaruhi oleh kebijakan pemerintah, pertumbuhan penduduk dan pembangunan ekonomi (Yin, 2011). Kebijakan pemerintah dalam perencanaan zonasi menjadi aspek penting dalam menanggulangi ledakan penduduk di daerah perkotaan. Kota Medan yang merupakan kota metropolitan di wilayah Sumatera menarik minat 
masyarakat disekitarnya untuk bermigrasi, mencari pekerjaan, maupun memperoleh pendidikan yang baik.

Keterbatasan sumberdaya yang dimiliki, serta ciri dan kondisi fisik geografis yang spesifik merupakan pertimbangan penting dalam perencanaan zonasi (Pinuji, 2018). Secara geografis, daerah di wilayah Sumatera umumnya didominasi oleh daerah perbukitan, khususnya di luar wilayah, tetapi tidak di wilayah pinggiran kota Medan. Oleh sebab itu, daerah seperti kabupaten Binjai dan Deli Serdang menjadi alternatif wilayah perencanaan zonasi di Sumatera Utara yang menjadi perhatian pemerintah dalam pembangunan ekonomi. Daerah Binjai dan Deli Serdang merupakan daerah strategis ekonomi, di mana banyak pabrik dan perusahaan didirikan.

Kondisi pusat kota dengan kepadatan penduduk yang tinggi dan fasilitas yang lengkap berbanding terbailk dengan kondisi pinggiran kota, sehingga dibutuhkan konversi lahan perkotaan yang lebih besar dari pada dipinggir kota (Lin, 2015). Akibat kepadatan penduduk yang tinggi di daerah perkotaan, tidak memungkinkan adanya konversi lahan perkotaan untuk pemukiman maupun kegiatan pengembangan ekonomi (Panuji, 2018). Selain itu, Kota Medan sekarang ini membutuhkan penambahan area hijau seluas sekitar 474.836 ha dari luas daerahnya sesuai dengan kemampuan menyerap emisi di wilayah, sehingga perlu menggalakkan program penanaman pohon (Silalahi, 2018).

Berdasarkan data Badan Pusat Statistika (2018), rata-rata pertumbuhan penduduk dari tahun 2000 hingga 2010 di kota Medan adalah sebesar 0,97\% per tahun sedangkan pertumbuhan penduduk Deli Serdang adalah $2 \%$ per tahun. Jika dilihat dari besarnya persentase pertumbuhan penduduk ini, secara sepintas dapat dinyatakan bahwa Deli Serdang lebih besar. Tetapi jika dilihat dari kepadatan penduduknya, BPS (2018) mencatat bahwa rata-rata kepadatan penduduk Deli Serdang adalah 944 jiwa/km2 dari sebelumnya 925 jiwa/km2 (BPS, 2017) lebih kecil dibandingkan kota Medan dengan rata-rata kepadatan penduduk sebesar 8.481 jiwa $/ \mathrm{km} 2$ yang sebelumnya 8.413 jiwa $/ \mathrm{km} 2$. Ini menunjukkan bahwa persentase pertumbuhan penduduk Deli Serdang sebesar $2 \%$ masih sebanding dengan luas wilayah yang dimilikinya sedangkan pertumbuhan penduduk kota Medan walaupun hanya 0,97\% tidak sebanding dengan luas wilayah yang tersedia. BPS mencatat jumlah penduduk di daerah Deli Serdang dan kota Medan dari tahun 2016 dan tahun 2017 adalah sebagai berikut:

Tabel 1. Jumlah Penduduk Deli Serdang dan Medan

\begin{tabular}{|c|c|c|c|c|c|c|}
\hline \multirow{2}{*}{ Tahun } & \multicolumn{3}{|c|}{ Deli Serdang } & \multicolumn{3}{c|}{ Medan } \\
\cline { 2 - 7 } & Desa & Kota & Total & Desa & Kota & Total \\
\hline 2016 & 431.757 & 1.640 .764 & $\mathbf{2 . 0 7 2 . 5 2 1}$ & 0 & $\mathbf{2 . 2 2 9 . 4 0 8}$ & $\mathbf{2 . 2 2 9 . 4 0 8}$ \\
\hline 2017 & 514.663 & 1.599 .964 & 2.114 .627 & 0 & $\mathbf{2 . 2 4 7 . 4 2 7}$ & $\mathbf{2 . 2 4 7 . 4 2 7}$ \\
\hline $\begin{array}{c}\text { Pertumbuhan } \\
(\%)\end{array}$ & 19,2 & $-2,49$ & 2,03 & 0 & 0,81 & 0,81 \\
\hline
\end{tabular}

Ketika konversi lahan yang tersedia tidak memungkinkan lagi untuk dilakukan di perkotaan, maka sebagai alternatif yang mungkin dilakukan adalah alih fungsi lahan darat (ladang) di pinggiran kota menjadi pemukiman penduduk untuk masyarakat kota seperti yang telah terjadi di pinggiran kota Jakarta (Bogor, Tanggerang, Bekasi, dan 
Depok). Ketika daerah pinggiran kota menyediakan lahan pemukiman yang disediakan untuk penduduk kota maupun desa, maka migrasi penduduk dari kota ke daerah pinggiran dapat terjadi. Migrasi yang tinggi merupakan suatu tantangan sekaligus ancaman bagi perkembangan suatu daerah (Ekawati, 2017).

Tantangan maupun ancaman akibat migrasi dapat bervariasi, tergantung dari faktor pendorong terjadinya migrasi. Makin mahalnya biaya hidup di daerah asal, adanya harapan akan memperoleh kesempatan untuk memperbaikan taraf hidup, kesempatan untuk memperoleh pendidikan yang lebih baik, serta keadaan lingkungan dan keadaan hidup yang lebihnya aman dan menyenangkan (Ekawati, 2017) menjadi alasan penduduk untuk bermigrasi.

Melalui Program Gerakan Nasional Pembangunan Sejuta Rumah yang digagas pemerintah diharapkan akan memuluskan aktivitas migrasi dari pusat kota ke pinggiran kota. Namun demikian, program ini hanya diperuntukkan bagi masyarakat berpenghasilan rendah dan menengah. Oleh karena itu, diharapkan bahwa program sejuta rumah ini akan banyak memberikan dampak yang cukup signifikan untuk mengurangi kepadatan penduduk diperkotaan.

Salah satu daerah yang mendapatkan izin program pembangunan sejuta rumah di kawasan Sumatera Utara adalah daerah Deli Serdang dan Kota Binjai. Desa Pecawir yang terletak dalam kawasan Deli Serdang menjadi tujuan developer property untuk membangun kompleks perumahan bersubsidi. Alasannya adalah karena daerah tersebut masih didominasi oleh lahan darat (perkebunan dan sawah), lokasinya mudah diakses dengan lingkungan yang aman dan nyaman sebagai tempat tinggal.

Dengan bermodal lokasi yang strategis serta pembiayaan yang terjangkau oleh masyarakat berpenghasilan rendah, menjadi alasan penduduk kota Medan untuk memperoleh hak kepemilikan rumah bersubsidi di desa Pecawir. Oleh karena itu, penelitian ini bertujuan untuk menganalisis migrasi penduduk melalui program rumah subsidi di daerah pinggiran kota Medan.

\section{METODE DAN FOKUS PENELITIAN}

Penelitian ini merupakan penelitian deskriptif yang memberikan gambaran migrasi penduduk kota Medan ke pinggiran kota dengan mengambil Perumahan Subsidi Griyaland Pecawir, Kabupaten Deli Serdang yang berada 20 KM dari Terminal AmplasMedan. Populasi penelitian ini adalah Masyarakat kota Medan yang mengambil Perumahan Subsidi Griyaland Pecawir sebanyak 300 Keluarga yang memiliki hak kepemilikan rumah subsidi tersebut. Sampel yang digunakan adalah seluruh keluarga yang memiliki hak kepemilikan rumah subsidi tersebut.

Data dikumpulkan menggunakan angket dan wawancara terkait alasan migrasi penduduk ke pinggiran kota Medan. Data yang diperoleh di analisis untuk mendeskripsikan faktor-faktor penyebab migrasi penduduk melalui program rumah subsidi di daerah pinggiran kota Medan. Variabel seperti jumlah penduduk kota Medan yang menetap di perumahan subsidi tersebut, jumlah penduduk yang bekerja di kota Medan, serta pengendalian kepemilikan rumah menjadi kunci penting dalam menganalisis proses migrasi penduduk tersebut. Adapun variabel seperti persentase 
pertumbuhan penduduk, jumlah penduduk dari tahun 2016 dan 2017 menjadi faktor pembanding migrasi yang terjadi dari kota Medan ke pinggiran kota (Deli Serdang).

\section{HASIL DAN PEMBAHASAN}

Berdasarkan informasi yang didapat diketahui bahwa jumlah penduduk yang menempati rumah subsidi tersebut ada sebanyak 13,33\%, sebagai rumah sewa ada sebanyak $1,33 \%$, sesekali ditempati sebanyak 2,67\%, dan belum ditempati sebanyak $82,67 \%$ dari total 300 kepala keluarga setelah 1 tahun lebih kompleks perumahan tersebut dibangun sebagaimana ditunjukkan pada tabel 2.

Tabel 2. Status Rumah Subsidi

\begin{tabular}{|l|l|c|c|}
\hline No. & \multicolumn{1}{|c|}{ Status Rumah Subsidi } & Jumlah & Persen \\
\hline 1. & Rumah Tinggal & 40 & 13,33 \\
\hline 2. & Rumah Sewa & 4 & 1,33 \\
\hline 3. & $\begin{array}{l}\text { Rumah persinggahan } \\
\text { (sesekali ditempati) }\end{array}$ & 8 & 2,67 \\
\hline $4 \cdot$ & Belum ditempati & $\mathbf{2 4 8}$ & 82,67 \\
\hline \multicolumn{2}{|c|}{ Jumlah } & $\mathbf{3 0 0}$ & $\mathbf{1 0 0 , 0 0}$ \\
\hline
\end{tabular}

Tabel 3 berikut ini menguraikan alasan yang dikemukakan para pemilik rumah subsidi mengambil kompleks Griyaland Pecawir, Deli Serdang. Tabel 3 menunjukkan bahwa ada $15,33 \%$ rumah yang menjadi tempat tinggal, o,67\% karena alasan tempat kerja yang lebih dekat, 34,33\% untuk disewakan, 49,67\% sebagai investasi.

Tabel 3. Alasan Kepemilikan Rumah Subsidi

\begin{tabular}{|l|l|c|c|}
\hline No. & \multicolumn{1}{|c|}{ Alasan Pemilik Rumah Subsidi } & Jumlah & Persen \\
\hline $\mathbf{1}$ & $\begin{array}{l}\text { Menjadi tempat tinggal daripada harus } \\
\text { mengontrak/sewa }\end{array}$ & 46 & 15,33 \\
\hline $\mathbf{2 .}$ & Lebih dekat dengan tempat kerjanya & $\mathbf{2}$ & 0,67 \\
\hline 3. & Untuk disewakan kembali & 103 & 34,33 \\
\hline 4. & Menjadi investasi masa depan (sesekali ditempati) & $\mathbf{1 4 9}$ & 49,67 \\
\hline \multicolumn{2}{|r|}{ Jumlah } & $\mathbf{3 0 0}$ & $\mathbf{1 0 0 , 0 0}$ \\
\hline
\end{tabular}

Kebutuhan akan lahan di daerah perkotaan seperti kota Medan memaksa pemerintah melalui Dinas Tata Kota mengambil strategi yang tepat untuk menyelesaikan persoalan ini. Salah satu upaya yang dapat dilakukan adalah mengadakan pembukaan lahan baru dan pengembangan lahan untuk tempat tinggal di daerah pinggiran kota.

Perubahan penggunaan lahan yang cepat di perkotaan dipengaruhi oleh empat faktor, yaitu: adanya konsentrasi penduduk dengan segala aktivitasnya; aksesibilitas terhadap pusat kegiatan dan pusat kota; jaringan jalan dan sarana transportasi; serta orbitasi, yakni jarak yang menghubungkan suatu wilayah dengan pusat-pusat pelayanan yang lebih tinggi (Cullingswoth, 1997). Solusi ini menjadi alternatif yang paling baik dalam upaya mengurangi jumlah penduduk di perkotaan agar migrasi ke pinggiran kota. 
Lahan sawah dan ladang di daerah pinggiran kota menjadi sasaran alih fungsi. Perubahan penggunaan lahan (sawah dan ladang) yang paling dominan adalah lahan permukiman yakni sebesar 50,32\% dari luas awal (Setiawan, 2016) yang hingga saat ini terus dikembangkan, terutama sebagai salah satu tujuan pembangunan nasional, yaitu penyediaan rumah tinggal murah bagi rakyat menengah ke bawah.

Ruang terbuka hijau yang sebelumnya kebun tradisional bernilai ekonomis, ekologi, saat ini secara perlahan berkurang dan hilang. Hanya tersisa pada lahan kawasan rumah-rumah yang dihuni oleh pendudukan dengan ekonomi atas yang ingin mempertahankan lingkungan tradisionalnya (Wulandari, 2018).

Namun demikian, tujuan pembangunan rumah tersebut banyak yang tidak tepat sasaran, semula bahwa pembangunan rumah tersebut diperuntukkan bagi masyarakat yang belum memiliki tempat tinggal, malah dimanfaatkan oleh pihak lain sebagai investasi. Hal ini juga terjadi pada Perumahan Subsidi Griyaland Pecawir, Kabupaten Deli Serdang, di mana 82,67\% rumah belum ditempati setelah satu tahun pembangunan dan 49,67\% di antaranya diperuntukkan sebagai investasi.

Dengan demikian, tujuan pemerintah dalam melaksanakan pembangunan rumah subsidi di daerah pinggiran kota tidak sepenuhnya mampu mengurangi jumlah pendudukan di daerah perkotaan. Migrasi penduduk yang seharusnya dapat mengurangi kepadatan penduduk di daerah perkotaan tidak dapat terlaksana dengan baik.

\section{PENUTUP}

Hasil penelitian ini menunjukkan beberapa kesimpulan, antara lain:

1) Hanya $17,33 \%$ dari jumlah rumah yang dibangun oleh Griyaland Pecawir yang dipergunakan oleh konsumen sebagai rumah tinggal dan $82,67 \%$ sisanya belum diketahui peruntukkannya.

2) Sebanyak 49,67\% dari jumlah rumah yang dibangun oleh Griyaland Pecawir yang diperuntukkan oleh konsumen sebagai investasi dan 34,33\% lainnya diperuntukkan sebagai rumah sewa.

3) Pembangunan perumahan dipinggiran kota Medan belum mampu mengurangi kepadatan pendudukan di kota Medan disebabkan rendahnya migrasi penduduk melalui program rumah subsidi di daerah pinggiran kota Medan.

\section{REFERENSI}

Badan Pusat Statistik. (2017). Statistik Daerah Provinsi Sumatera Utara 2017. Medan: BPS Sumatera Utara.

Badan Pusat Statistik. (2018). Provinsi Sumatera Utara Dalam Angka 2018. Medan: BPS Sumatera Utara.

Ekawati, R., Herartri, R., Nuraini, Rahayuwati, L., \& Sukamdi. (2017). Fertilitas Migran dan Faktor yang Memengaruhi Fertilitas di Jawa Barat. Jurnal Populasi, 25(2), $44-53$. 
Lin, T., et al. (2015). Spatial Pattern of Urban Functional Landscape along an UrbanRural Gradien: A case Study in Xiamen City, China. Elsevier: International Journal of Applied Earth Observation and Geoinformation, 46, 22-30.

Mulyani, W.P. (2016). Dinamika Kesejahteraan Penduduk di Banjarnegara. Majalah Geografi Indonesia, 3o(1), 96-103

Pinuji, S., Suhattanto, M.A., \& Arianto, T. (2018). Dinamika dan Tantangan Penggunaan dan Pemanfaatan Tanah di Wilayah Pulau Kecil. Bhumi, 4(1), 104116.

Setiawan, B., \& Rudiarto, I. (2016). Kajian Perubahan Penggunaan Lahan Dan Struktur Ruang Kota Bima. Jurnal Pembangunan Wilayah E Kota, 12(2), 154-168.

Silalahi, J. \& Subarudi. (2018). Analisis Kebutuhan Hutan Kota di Kota Medan, Sumatera Utara. Retrieved from https://www.researchgate.net/publication/324102936.

Wulandari, E., \& Aulia, F. (2018). Pengaruh Morfologi Kota terhadap Ekologi Perkampungan Tradisional di Kota Banda Aceh, Indonesia. Jurnal Arsitektur Zonasi, 1(1), 45-54.

Yin, J., et al. (2011). Monitoring Urban Expansion and Land Use/Land Cover Changes of Shanghai Metropilitas Area During the Transitional Economy (1979-2009) in China. Elsevier: Environment Monitoring Assessment, 177, 609-621. 